\title{
Moral Virtue as Knowledge of Human Form
}

\section{Micah Lott}

\section{Moral Goodness and Human Form}

In an essay discussing practical wisdom and its relation to philosophy, Alasdair MacIntyre makes the following claim:

We all of us begin our adult lives with some classification and rank ordering of goods, some hierarchy of ends, some implicit or partially explicit conception of human good that we have acquired from our upbringing and from the culture into which that upbringing and was an initiation. (emphasis mine) ${ }^{15}$

In this essay and elsewhere, ${ }^{16}$ MacIntyre elaborates an Aristotelian account of moral goodness, which gives central place to the notion of human good. ${ }^{17}$ On the Aristotelian view, human good plays two important roles. First, human good determines what counts as goodness and badness in human action. ${ }^{18}$ And hence human good determines what counts as moral goodness, for moral evaluations speak to excellence and defect in the action and character of human beings considered as such. As one proponent puts it:

“ 'That was morally good action' is equivalent to 'Qua human action, that was good' or 'That was good human action' and 'That was a morally bad human

\footnotetext{
15 "Aristotle against some modern Aristotelians" in his collection of essays Ethics and Politics 33. ${ }^{16}$ See especially Dependent Rational Animals (Open Court: LaSalle: 1998)

${ }^{17}$ For the purposes of this essay, I am interested in the kind of Aristotelian account I take to be shared by MacIntyre, Phillipa Foot and Michael Thompson - among others. There are differences between these thinkers, but those do not concern me here.

${ }^{18}$ See, e.g., Philippa Foot Natural Goodness, 44.
} 
action' is equivalent to 'Qua human action, that was bad' or 'That was a bad human action.' "19

According to this Aristotelian account, moral judgments share a conceptual structure with judgments of excellence and defect in other living things, including plants and animals. In each case, the goodness of parts and activities is understood in relation to the good of the being in question as defined by its life-form -in relation to a particular plant-good or animal-good, in the one case, and in relation to human good in the other. The notion of human good, then, is central to what counts as good action for human beings as such i.e. moral goodness.

In addition, human good is also at the center of ethical understanding. What the morally virtuous person grasps - what she reasons well about in a practical way - is human goodness, with respect to action and choice. And here there is a difference between the human case and other life-forms. On the one hand, the Aristotelian asserts that the notion of human good is conceptually similar to the notion of good, or flourishing, as applied to other living things. ${ }^{20}$ With humans, just as with oaks and tigers, we evaluate individuals in light of the form which they bear. ${ }^{21}$ On the other hand, however, our knowledge of human form - or, equivalently, our knowledge of human good - is of a different sort from our knowledge of other life-forms. For in the case of other life-forms, humans come to learn about them through empirical observation. But in

\footnotetext{
${ }^{19}$ G.E.M. Anscombe "Human Action" in Human Life, Ethics and Action

${ }^{20}$ Cf. MacIntyre's assistance on the univocity of the concept of "flourishing" as applied to humans and other living things in Dependent Rational Animals.

${ }^{21}$ For an account of life-form judgments, see Michael Thompson Life and Action part I (Cambridge, MA: HUP, 2008).
} 
the case of human-form, we come to know what "the human" is by coming to know how to act. We acquire our (initial) understanding of human form from living as a human.

In this paper, I want to explore this idea, in order to spell out the claim that knowledge of human form is "from within", whereas knowledge of other life-forms is "from without." What is meant by "from without" is perhaps more clear: We learn about other life-forms by observing them. We learn about them empirically. However, what is meant by knowing "from within" is less clear. My question, then, is this: how and why does being brought up as a human being - being educated to have a developed rational will - provide one with a knowledge of human form (or, human good)? My question picks up the idea expressed in the quote from MacIntyre above, but it has a slightly different focus. For whereas MacIntyre speaks of all adults having "some" conception of human good, I am asking about knowledge of the human form, which implies a true conception of human good. My focus, accordingly, will be on the knowledge of human form as given through the practical virtues, since I take it that the virtues provide a person with a correct perception of human action and a correct understanding of human good. So the question is: how does the possession of the moral virtues provide a human being with knowledge of the very form she bear - the very form that is realized in her virtuous actions?

2. Moral Virtue and Connatural Knowledge

To make progress on this question, let us begin with Elizabeth Anscombe's discussion of connatural knowledge. Anscombe describes connatural knowledge as "the 
sort of knowledge someone has who has a certain virtue"22 It is "the capacity to recognize what action will accord with and what ones will be contrary to virtue." ${ }^{23}$ The idea of connatural knowledge, then, embodies that thought that part of having a virtue is the ability to recognize which actions accord with it, and which are against it. However, what is distinctive about connatural knowledge is not only the object known - what actions will count as courageous, generous, just, etc. - but the way it is known. Connatural knowledge comes through a person's disposition toward virtuous actions, and away from vicious ones. In contrast, a merely clever person may know that a certain action would be just, or mean, but he knows it in a different way - "out of a certain sharpness of intelligence."

To see the difference between the connatural knowledge of the virtuous and knowledge of the merely clever, consider a particular case in which there is a debt owed. The person with the virtue of justice recognizes the fact of a debt as a reason to repay it. Thus her reasoning can be represented as follows:

1) I owe Sam a debt. (Or, to make it a case for charity: Sam is in need of help)

2) The time has come to repay, and I have the means to do so. (I am positioned to help)

\section{3) So I'll pay! (So I'll help!)}

If you were to ask the just person what action was in accord with justice here, she would be able to tell you - e.g. repaying the debt on Tuesday, when she usually sees Sam. And

\footnotetext{
${ }^{22}$ See her essay "Knowledge and Reverence for Human Life," 60. In Three Rival Versions of Moral Enquiry, MacIntyre also makes mention connatural knowledge as a form of moral knowledge that is not theoretical, 128.

${ }^{23}$ Ibid.
} 
she could also tell you which actions would be against justice - e.g., lying to Sam and telling him she doesn't have the money, or changing her phone number to avoid him. She knows which action accord with justice, and which are against it. However, she knows what the just action is through her perception of the situation and what it requires - via her recognition that she would be justified in repaying the debt, her recognition that the fact of the debt owed is a good reason to repay it. ${ }^{24}$ She perceives the situation in light of certain salient considerations, and she recognizes that those considerations have a claim on her actions. ${ }^{25}$ That she does so such is partly constitutive of having the virtue of justice. She knows that a certain action is just through her understanding of what she ought to do. ${ }^{26}$

The merely clever man can also know that repaying the debt will count as just. But we cannot represent him coming to this knowledge as the virtuous does - i.e. through the recognition of the fact of the debt as a reason to repay. For the fact that he does not reason that way is part of his being merely clever, and not just. The clever man can recognize that repaying the debt is the just action, and that other options are unjust ones,

\footnotetext{
${ }^{24}$ Issue: How to think about this recognition in relation to inclination, which is what Anscombe herself emphasizes. Cf. Anselm Muller's point in "Acting Well" - the recogniton of such reasons is a practical recognition: the form it takes is drawing the inference by acting.

${ }^{25}$ Which is to say, she recognizes the validity of a form of practical inference, and she recognizes it in a practical way - by making the inference and acting.

${ }^{26}$ In her essay, Anscombe also says that the just person has "a connatural knowledge of the worth of a human being, of the dignity of human nature." 26 At first, such knowledge seems very different from knowing what acts accord with virtue. But we can see the connection, I think, if we recognize that the worth of a human being just is the way that a human being merits a special kind of treatment. To say that a human being has dignity is to say that humans deserve to be responded to with respect. And the virtue of justice is a matter of showing this respect. In choosing just actions and avoiding unjust ones, the just person acts in accordance with and in recognition of the humanity of others as the grounds for dealing with them as he does. Thus, the practical reasoning of the just person manifests a recognition of the normative significance of others, and that is a practical recognition of their worth as human beings.
} 
but this will be because of an understanding of how the concept of 'justice' works, and not in virtue of recognizing considerations of justice as having a direct claim on how he should act. Thus the merely clever man can recognize that an action would be just or unjust, but how this fact figures into his reasoning will be different from the case of the just. We can imagine him reasoning as follows:

1) I owe Sam a debt. (Or, to make it a case for charity: Sam is need of help)

2) Not repaying your debts counts as unjust. (Helping others is considered charitable)

3) People look down on unjust actions, punishing the unjust with social ostracism. (People look down on uncharitable actions, criticizing them).

4) I want to avoid social ostracism (I don't want to have my actions criticized).

5) So I'll repay the debt! (So I'll help!)

Here, the fact that an action counts as just figures into the reasoning of the merely clever person, but it is fact is of instrumental significance, and that is part of his being merely clever and not just. Unlike the virtuous, he cannot be said to know that repaying the debt is just simply by considering what to do in the situation. ${ }^{27}$

\section{Virtue as Knowledge Human Form}

\footnotetext{
${ }^{27}$ It seems we can say, then, that the vicious person's knowledge that an action will count as just is "from without" - it comes from observing how other humans talk and react. And one could gain this knowledge without living a human life; there is no essential connection between having knowledge in this way and acting well as a human being. For example, an alien anthropologist might realize that such-and-such an action will be considered 'just' simply by observing how our species works.
} 
So far I have been trying to spell out a special sort of knowledge that the moral virtues give to their possessor, following some suggestions about connatural knowledge from Anscombe. I now what to show that this special sort of knowledge amounts to a knowledge of human form, and thus that the moral virtues provide knowledge of human form.

A moral virtue is distinguished by some characteristic type of response to a given type of consideration. Thus the virtue of courage is distinguished by a response of boldness, or steadfastness, in the face of things recognized as dangerous, while the virtue of helpfulness involves perceiving the needs of others and taking those needs as a reason to provide assistance. As the examples from the last section suggested, what distinguishes the virtuous person are the reasons for which she acts. The responses of the moral virtues embody distinctive patterns of practical inference. The premises for such inference are considerations present in the situation, and the conclusions are the actions which are justified by those considerations. Thus a virtue involves: 1) seeing situations in light of salient normative considerations -i.e. registering certain factors as considerations in determining one's actions (e.g. "there is someone who needs some help") and 2) drawing certain practical conclusions from those considerations (e.g. "so I'll help him!'). The virtuous person recognizes the features of the situation as meriting a practical response (in emotion and action) and she responds accordingly.

For example, the virtue of gratitude requires 1) that you recognize when another has given you a (undeserved) good and 2) that you regard this as a reason to express your thanks to that person. In addition, the practical reasoning relevant to virtue culminates in 
particular action, and this means that the virtuous will take into account various factors in determining what is right to do here and now. The virtue of gratitude, then, will lead a person to express her thanks in a way that is responsive to particular features of the situation, including considerations relevant to the other virtues. (Thus, she will not steal something to give to another as an expression of thanks, since stealing is a violation of justice). So the grateful person's reasoning can be represented thusly:

1) she helped me out so much with that project, and really didn't have to

2) so I'll express my thanks!

3) a good way to express my thanks is getting her that novel she wants to read.

4) so I'll get her the novel!

So it is part of virtue that one reasons well - that one correctly grasps what one ought to do and does it. However, the virtues are also the practical excellences of human beings considered as such. That is, they provide an account of what counts as acting well for us as human beings. The moral virtues speak to our goodness qua human beings, and not to our goodness qua something more particular or local - qua Americans, or women, or people with our aesthetic tastes, etc. So if the virtuous person knows what she ought to do, and if the virtues characterize the goodness in human action, then the virtuous person also knows what a human being ought to do. To possess a virtue is to know how a human should act. However, to know how a human should act is to know what the good of the human being is, what counts as living and acting well for a human. And 
knowledge of that just is knowledge of human form. Thus the virtuous possess, through the understanding embodied in practical inference, a knowledge of human form.

If this sounds odd, we should remember that virtue is not manifest only in discreet "acts of virtue," as if those could be set off from the "normal" or "neutral" things that a person does. Rather, as MacIntyre stresses, the virtues apply to all domains of life. ${ }^{28}$ The moral virtues speak to everything a human being does in a way that is guided by reasons: how a human should eat her dinner, repay her debts, earn a living, play music with friends, etc. The way in which any of these things is do be done is a matter of virtue; considerations of virtue are relevant to all of them. Thus the knowledge of human form that comes via the virtues will be manifest across the whole range of human activities that are done on the basis of reasons. It is a knowledge that is on display in the living of a human life, and it an essential part of living that sort of life.

While oak trees and sparrows have a distinctive good, it is no part of those lifeforms for the adults of the species to have a conception of oak-good or sparrow-good. In contrast, it belongs to "the human" to form a conception of its own form of life. And in this respect, our knowledge of our own form has a different status for us than our knowledge of other life-forms. For suppose it were true, as the result of a massive effort of botanical education, that every human now living entered adulthood with the knowledge of oak-form, with a conception of "the oak" and what its flourishing required. Even if all humans happen to be educated about oaks, and even if knowing about oakform is valuable and worthwhile, such knowledge is not proper to the human in the way

\footnotetext{
${ }^{28}$ See Dependent Rational Animals -quote.
} 
that knowledge of human-form is proper. Such knowledge of oak-form is accidental in the life of the human being in a way that knowledge of human-form is not: A human being as such is not defective for failing to knowing about oaks, whereas a human being with no grasp of human form is defective qua human.

This should come as no surprise, in light of what we have seen about virtue. For virtue brings with it a knowledge of human form that comes through the virtuous person's understanding of what counts as a reason for what. A person no grasp of human form, then, would possess none of the virtues and have no grasp of what counts as a reason for what, and surely that would be a defective sort of human life. 